ROCZNIKI HUMANISTYCZNE

Tom LXVII, zeszyt $10-2019$

DOI: http://dx.doi.org/10.18290/rh.2019.67.10-7

BARTŁOMIEJ MALISZEWSKI

\title{
KU ABSENCJI INTERFERENCJI - SPOSOBY \\ UTRWALANIA POPRAWNYCH FORM GRAMATYCZNYCH W NAUCZANIU JĘZYKA POLSKIEGO MŁODZIEŻY Z UKRAINY
}

Nauka języka polskiego w grupach słowiańskojęzycznych przebiega nieporównywalnie szybciej niż w pozostałych grupach, choć dużym wyzwaniem dla lektora i uczących się jest zwalczanie interferencji zewnątrzjęzykowych. Stanowią one nieodłączny składnik procesu nauczania, poczynając od częstych i banalnych błędów z pierwszych lekcji (np. *mam na imia, *u mnie telefon, *moj nomier to... ${ }^{1}$ ), po mniej liczne uchybienia, które pojawiają się w konstrukcjach używanych na wyższym poziomie kompetencji językowej (np. *obwiniać, oskar$\dot{z} a c ́$ kogoś w czymś, ukr. звинувачувати когось у чомусь, ros. обвинять кого в чем). Przydatna w procesie nauczania staje się znajomość błędów popełnianych na skutek interferencji. Nauczyciel może bowiem dobierać zadania, które służą utrwalaniu właśnie tych form, które są częstym przedmiotem interferencji, a z kolei uczący się - którzy są świadomi mechanizmów popełnianych błędów - stają się bardziej ostrożni przy wykonywaniu ćwiczeń gramatycznych oraz przy formułowaniu (pisemnych bądź ustnych) wypowiedzi.

W pierwszej części niniejszego artykułu przedstawimy błędy wyekscerpowane z wypowiedzi młodych Ukraińców (w wieku 16-17 lat), którzy - ucząc się języka polskiego od podstaw - przygotowują się do egzaminu certyfikatowego z języka polskiego na poziomie B1. W drugiej części pracy przedstawimy zaś propozycje ćwiczeń, których celem jest utrwalanie właściwych form oraz związanych z nimi reguł. (Koncentrujemy się tu na zadaniach przeznaczonych właśnie dla

Dr BartŁomiej Maliszewski - adiunkt dydaktyczny w Centrum Języka i Kultury Polskiej dla Polonii i Cudzoziemców Uniwersytetu Marii Curie-Skłodowskiej w Lublinie; e-mail: bmalisz@wp.pl

${ }^{1} \mathrm{~W}$ tekście głównym błędnie użyte formy oznaczono gwiazdką. 
młodzieży, starając się uwzględniać jej oczekiwania i potrzeby, by w ten sposób zwiększać efektywność nauczania).

\section{INTERFERENCJE GRAMATYCZNE}

Pisemne prace Ukraińców, przystępujących do egzaminu certyfikatowego na poziomie B1, świadczą o tym, że wśród popełnianych błędów przeważają uchybienia dotyczące dwóch kategorii: ortografii i gramatyki ${ }^{2}$. O ile jednak niezbyt dobra znajomość ortografii (na tyle opanowanej, by zapewnić zrozumiałość tekstu pisanego) nie stanowi przeszkody, by zdać egzamin certyfikatowy ${ }^{3}$, o tyle niedostateczny stopień kompetencji gramatycznej często uniemożliwia osiągnięcie tego celu. Poprawność gramatyczna podlega bowiem ocenie w odrębnej części egzaminu ${ }^{4}$, a także jest brana pod uwagę przy ewaluacji dwóch innych części - wypowiedzi pisemnej i ustnej.

Literatura językoznawcza oraz glottodydaktyczna jest pełna przykładów interferencji, które pojawiają się w wypowiedziach osób posługujących się różnymi językami ${ }^{5}$. Po błędach (gramatycznych, leksykalnych, fonetycznych), jakie

${ }^{2}$ Zob. A. Dunin-Dudkowska, B. Maliszewski, Jak lepiej (nie) pisać? O błędach popetnianych przez Ukrainców zdajacych egzamin certyfikatowy z języka polskiego jako obcego, w: Polonistyka w XXI wieku: między lokalnym a globalnym, red. A. Krawczuk, I. Bundza, Kijów: Firma INKOS 2018.

${ }^{3} \mathrm{Na}$ egzaminie certyfikatowym z języka polskiego jako obcego na poziomie B1 ocenie podlega wykonanie zadania, bogactwo językowe oraz poprawność gramatyczna, ortograficzna i interpunkcyjna, a maksymalna liczba punktów przyznawanych za ortografię i interpunkcję stanowi jedynie $10 \%$ sumy punktów, które można uzyskać za wypowiedź pisemną.

${ }^{4}$ Struktura i czas egzaminu na poziomie B1 oraz zasady jego oceny różnią się jednak w zależności od wersji egzaminu (dla osób dorosłych oraz dostosowanej do potrzeb dzieci i młodzieży). Poprawność gramatyczna stanowi osobną część w wersji dla osób dorosłych, podczas gdy w wersji dla juniora testowanie znajomości struktur gramatycznych towarzyszy zadaniom na rozumienie tekstu.

${ }^{5}$ Specyfika nauczania wschodnich Słowian oraz pojawiające się tu interferencje stanowią temat licznych opracowań - zob. m.in. O. BARAniwska, Polsko-ukraińskie interferencje gramatyczne i leksykalne w nauczaniu języka polskiego jako obcego, w: Literatura, kultura i język polski w kontekstach i kontaktach światowych, red. M. Czermińska, K. Meller, P. Fliciński, Poznań: Wydawnictwo Naukowe UAM 2007; T. Czernysz, Polsko-ukraińskie pułapki językowe: korzyści i trudności nauczania języka polskiego w kontekście bliskości lingwogenetycznej i typologicznej, w: Nauczanie języka polskiego jako obcego i polskiej kultury w nowej rzeczywistości europejskiej, red. P. Garncarek, Warszawa: Uniwersytet Warszawski 2005; A. DĄBROwSka, U. Dobesz, M. Pasieka, Co warto wiedzieć. Poradnik metodyczny dla nauczycieli języka polskiego jako obcego na Wschodzie, Warszawa: Ośrodek Rozwoju Edukacji 2010; M. GóRECKI, M. StaWsKa, Błędy językowe charakterystyczne dla młodzieży polskiej ze Wschodu, w: Metodyka kształcenia językowego Polaków ze Wschodu, red. J. Mazur, Lublin: Wydawnictwo UMCS 1993. 
nadawca popełnia w obcej mowie, można rozpoznawać narodowość mówiącego. Z 40 pisemnych prac młodych Ukraińców, którzy uczą się języka polskiego od podstaw, by po 7 czy 8 miesiącach przystąpić do egzaminu certyfikatowego na poziomie B1, wynotowaliśmy następujące błędy (zasób leksykalny analizowanych tekstów liczył ok. 8000 słów):

\begin{tabular}{|c|}
\hline $\begin{array}{c}\text { Interferencje gramatyczne - rodzaje i przykłady typowych błędów } \\
\text { popełnianych przez Ukraińców uczących się języka polskiego } \\
\text { (na poziomach od A1 do B1) }\end{array}$ \\
\hline fleksja imienna \\
\hline $\begin{array}{l}\text { 1. Błędne formy zapożyczeń, które w języku polskim bądź innych językach słowiańskich kończą się } \\
\text { na samogłoskę: prognoz, diagnoz, gryp, aspirin, temp, problema, drama, co skutkuje ich niewłaścią } \\
\text { odmianą. }\end{array}$ \\
\hline $\begin{array}{l}\text { 2. Niewłaściwa postać zapożyczeń r. nijakiego zakończonych w języku polskim na -um: centr, gimna- } \\
\text { zja; odmiana rzecz. r. nijakiego zakończonych na -um: do liceuma. }\end{array}$ \\
\hline 3. Problemy z -e ruchomym: zadzwonitem po Ireka. \\
\hline $\begin{array}{l}\text { 4. Błędne formy dopełniacza 1. poj. rzecz. męskich nieżywotnych; niewłaściwa dystrybucja końcówek } \\
-a,-u \text { : uśmiecha, lista. }\end{array}$ \\
\hline $\begin{array}{l}\text { 5. Błędne formy celownika 1. poj. rzecz. r. męskiego zakończonych na spółgłoskę; używanie końców- } \\
\text { ki -u zamiast -owi: dzięki profesjonalizmu, przy rzecz. miękkotematowych r. żeńskiego dodawanie } \\
\text { końcówki -e: dziękuję Anie. }\end{array}$ \\
\hline $\begin{array}{l}\text { 6. Błędne formy biernika 1. poj. zaimków, przymiotników i rzecz. zakończonych na - } a \text {; wprowadzanie } \\
\text { końcówki - u: taku muzyku, тојu тати. }\end{array}$ \\
\hline $\begin{array}{l}\text { 7. Błędne formy narzędnika 1. poj.; stosowanie końcówki -om zamiast -em: numerom, brak litery i po } \\
-k,-g: \text { z Markem, używanie końcówki - } u \text { lub -ej zamiast -ą: z babciej. }\end{array}$ \\
\hline $\begin{array}{l}\text { 8. Błędne formy miejscownika 1. poj. rzecz. miękkotematowych: w tym miesiace, o złym dnie, w kuch- } \\
\text { nie, przy ulice, w wypadku rzecz. twardotematowych brak zmiękczenia (-e zamiast -ie): w Kijowe, } \\
\text { w filme. }\end{array}$ \\
\hline
\end{tabular}

D. IzDEBSKa-DŁugosz, „CZyje są te syny?”, czyli o błędach w rodzaju męskoosobowym popetnianych przez studentów ukraińskojęzycznych, w: Horyzonty nauczania języka polskiego jako obcego, red. A. Roter-Bourkane, A. Kwiatkowska, Poznań: TetraStudio 2016; J. KowALEwSKi, Czy można się uczyć na błędach? Wnioski dydaktyczne wynikające z analizy błędów popetnianych przez uczacych się języka polskiego na Ukrainie, w: Język polski i polonistyka w Europie Wschodniej: przeszłość i współczesność, red. I. Bundza, J. Kowalewski, A. Krawczuk, Kijów: Firma INKOS 2015; A. KRAwCZUK, Błędy gramatyczne studentów polonistyki lwowskiej spowodowane polsko-ukrainska interferencja, „Postscriptum” 2(2006), s. 137-153; B. MaLiszewski, Per errata ad astra-zwalczanie interferencji gramatycznych $w$ procesie nauczania języka polskiego studentów ze Wschodu, w: Błąd w literaturze, kulturze i językach narodów słowiańskich, red. M. Dziwisz et al., Lublin: Wydawnictwo UMCS 2014; G. PRZECHODZKa, Z problematyki interferencji językowej w nauczaniu języka polskiego Polaków ze Wschodu, w: Metodyka kształcenia językowego Polaków ze Wschodu, red. J. Mazur, Lublin: Wydawnictwo UMCS 1993. 
9. Używanie form mianownika w funkcji wymaganego wołacza (pod wpływem języka rosyjskiego): Droga Anna!; błędne formy wołacza (brak oboczności): Michałe, przy rzecz. miękkotematowych niewłaściwe końcówki: Droga Marie.

10. Błędne formy mianownika 1. mn. rzecz. miękkotematowych: nauczycieli sa, lekarzy postawili, moi przyjacieli.

11. Błędne formy mianownika 1. mn. rzecz. męskoosobowych: kolegi oraz łączących się z nimi przymiotników, zaimków i liczebników: różne ludzie.

12. Błędne formy mianownika i biernika 1. mn. zaimków dzierżawczych, wskazujących, względnych oraz przymiotników r. niemęskoosobowego: zieloni oczy, czarny włosy, moi dzieci, jaki konsekwencje, taki problemy.

13. Błędne formy dopełniacza 1. mn. rzecz. miękkotematowych r. męskiego: lekarzów.

14. Błędne formy celownika 1. mn. rzecz., wprowadzanie końcówki -am: osobam.

15. Błędne formy biernika $1 . \mathrm{mn}$. rzecz. niemęskoosobowych określających istoty żywe: ona ma dwóch kotów, lubi psów.

16. Błędne formy biernika 1. mn. zaimków: ono, one (używanie form go, jego, ich zamiast je): dała mi go (o życiu), kocham ich (o dzieciach).

17. Przy stopniowaniu opisowym przymiotników i przysłówków błędy wynikające ze stosowania słów duże, dużo zamiast 'bardzo': więcej, najwięcej inteligentny (більш, найбільш інтелігентний).

\section{fleksja werbalna}

1. Błędne formy czasu teraźniejszego: przypisywanie czasownikom niewłaściwych typów koniugacji, tworzenie form typu: on kochaje, stuchaje na wzór: він кохає, слухає (oraz niektórych polskich czasowników koniugacji -ę, -esz: daje, wstaje); błędne formy 1 os. 1. poj. i 3 os. 1. mn. czasowników, w których nastąpił przegłos: ja bierę (я беру).

2. Stosowanie błędnych form czasu przeszłego: brak odpowiednich końcówek osobowych: ja myślata (я думала), używanie form z końcówką -li wraz z rzecz. r. niemęskoosobowego: dzieci pojechali, nasze drogi się rozeszli.

3. Błędne formy trybu rozkazującego; stosowanie końcówki -i/-y w 2 os. 1. poj: zadzwoni (подзвони), napiszy (напиши).

4. Problemy z formami czasu przeszłego czasownika jeść, paść oraz ich wyrazów pokrewnych, pomijanie grup $d l, d t$ : oni jeli tort (вони їли торт), okulary upaty (окуляри впали).

5. Problemy z formą czasu przeszłego czasowników bać, stać: bojat się (він боявся), stojat (він стояв).

\section{składnia}

1. Błędne używanie biernika po zaprzeczonych czasownikach: nie zapomnij wziąć dokumenty (не забудь взяти документи).

2. Nieużywanie czasownika posiłkowego być: ona młodsza ode mnie (вона молодша за мене), przyroda tam piękna (природа там гарна).

3. Nadużywanie konstrukcji z bezokolicznikiem: poprosił mnie podać sól (він попросив мене передати йому сіль).

4. Problemy ze składnią zdań dopełnieniowych ze spójnikiem żeby: prosiłaś mnie, żeby opowiedziała ci...

5. Łączenie czasownika być z formami bezosobowymi czasownika: było zrobiono. 
6. Błędy w związkach rządu: stucham muzykę (я слухаю музику), on pracuje lekarzem (він працює лікарем), ona mi się uśmiechnęta (вона мені посміхнулася), czekamy gości (ми чекаємо гостей).

7. Liczne błędy w wyrażeniach przyimkowych: chodzi na rzekę (він ходить на ріку), z poczatku 'od początku' (з початку), nadużywanie przyimka dla: pokój dla pracy (кімната для роботи), рrzy stopniowaniu przymiotników i przysłówków konstrukcje typu: młodsza na pięć lat (молодша на п’ять років).

8. Stosowanie konstrukcji składniowych: jej pięć lat (їй п’ять років), и mnie, и ciebie jest (nie ma) w znaczeniu '(nie) mam, masz': u mnie nie ma braci (у мене немає братів), używanie konstrukcji: trzeba mi, potrzeba mi, potrzebno mi w znaczeniu 'muszę coś zrobić', jeden jednemu (drugiemu) (один одному) w znaczeniu 'sobie, nawzajem'.

9. Stosowanie długich form zaimków osobowych po czasownikach: napisz mnie (напиши мені), dziękuję tobie (дякую тобі), stuchasz jego (слухаєш його).

10. Błędne użycie form czasownika w połączeniach z podmiotem w dopełniaczu: dużo studentów kupili (багато студентів купили).

11. Błędy w tworzeniu strony biernej (używanie narzędnika sprawcy): portret wykonany Warholem (виконаний Уорхолом портрет).

12. Problemy z odpowiednim użyciem czasowników: stać, stać się, zostać: staliśmy bliskimi przyjaciótmi (ми стали близькими друзями).

13. Błędy w szyku: Czarne Morze (Чорне море), ty mi podobasz się (ти мені подобаєшся).

14. Używanie zaimka jaki zamiast który: Mieszkam z Pawłem, jaki jest moim przyjacielem.

15. Używanie przyimka za w znaczeniu 'przez, w ciągu': schudła za miesiąc (схудла за місяць).

słowotwórstwo

1. Błędne formy przysłówków: ciekawo (цікаво), nowoczesno (сучасно), spokojno (спокійно).

2. Stosowanie niewłaściwych prefiksów: podzwonić (подзвонити) jako 'zadzwonić', wypowiedzieć (відповісти) јаko 'odpowiedzieć', rozpowiedzieć (розповісти) јаko 'opowiedzieć', wpaść (впасти) јако 'upaść', pomierzyć (поміряти) јako 'przymierzyć'.

3. Błędne posługiwanie się czasownikiem zmóc jako formy dokonanej od móc: nie zmogłam (я не змогла).

4. Dobór nieodpowiednich formantów słowotwórczych w przymiotnikach odrzeczownikowych: $d z i e c k i$ pokój (дитяча кімната), telefonny пuтеr (телефонний номер), koncertna sala (концертний зал).

5. Brak odpowiednich oboczności w podstawach słowotwórczych: moja przyjacielka (моя приятелька).

Choć zasób błędów wynikających z interferencji jest nieograniczony, to jednak ich najczęstsze rodzaje są łatwe do uchwycenia. Pojawia się zatem istotne pytanie, w jaki sposób zmniejszać liczbę interferencji na rzecz pożądanych form. Dużo zależy tu oczywiście nie tylko od samego nauczyciela, ale i postawy osób uczących się języka. Podczas lekcji widać, że jedni uczniowie szybciej przyswajają sobie reguły, są ostrożniejsi w doborze słów oraz konstrukcji gramatycznych, skrupulatnie zapisują sobie nowe rzeczy, zadają pytania, starają się konstruować dłuższe wypowiedzi, podczas gdy inni uczniowie wpadają w koleiny interferencji bądź bazują na tym, co już dobrze znają, korzystając z szablonowych, najczęściej powtarzanych formuł. Wskazane są zatem ćwiczenia, które pozwalają 
przypominać reguły gramatyczne oraz sprawdzać ich znajomość, służąc przy tym aktywizowaniu uwagi uczniów.

\section{EKSPONOWANIE NOWYCH KONSTRUKCJI}

Cenną rzeczą, która jest często stosowana w podręcznikach, jest eksponowanie nauczanych konstrukcji językowych w tytułach lekcji oraz ich częściach (np. Jaki jesteś? Małe zakupy). Krótki tytuł pozwala zwrócić uwagę na określoną regułę gramatyczną (np. używanie orzecznika przymiotnikowego w mianowniku, formy przymiotnika w rodzaju niemęskoosobowym), a gdy uczeń nie stosuje danej reguły, łatwo odnaleźć i wskazać użytą w tytule konstrukcję, by w ten sposób skłonić mówiącego do zauważenia popełnionego błędu i jego korekty. W początkowym etapie nauczania warto też rezerwować stałą część tablicy na zapis nowych konstrukcji, które mogą być przedmiotem interferencji. Gdy mówiący popełnia błąd, wskazujemy markerem przykład poprawnej formy, sygnalizując uczniowi konieczność korekty. Gdy pojawiają się problemy z jej dokonaniem, przypominamy odpowiednią zasadę. Ważne, by nowe konstrukcje były dobrze widoczne (w podręcznikach, rozdawanych materiałach dydaktycznych, na tablicy) i często słyszane, pojawiając się w wypowiedziach nauczyciela oraz uczących się.

Gdy uczymy języka polskiego w Polsce, warto robić zdjęcia okolicznym szyldom, reklamom, tabliczkom, napisom i posługiwać się wyświetlanymi fotografiami przy wprowadzaniu poszczególnych reguł. Dzięki temu odwołujemy się do tego, co bliskie, znane, często spotykane, a zarazem uwrażliwiamy uczniów na zasady gramatyczne oraz ich wszechobecność. Na przykład fotografia znajdującej się na sąsiedniej ulicy reklamy o treści: Soczewki kontaktowe. Najlepsze, najtańsze. Ceny internetowe! staje się przydatna przy omawianiu końcówek przymiotnika rodzaju niemęskoosobowego oraz przy nauczaniu zasad stopniowania, a uczeń, który po lekcji będzie przechodził obok danej tablicy, zapewne zwróci na nią uwagę, dostrzegając w czytanym tekście wskaźnik omawianych reguł.

\section{SPOSOBY ZWALCZANIA INTERFERENCJI - PROPOZYCJE ĆWICZEŃ}

Kluczową rzecz w nauce języka stanowi wielokrotne powtarzanie słownictwa, reguł, krótkich wypowiedzi. Powtarzalność czynności dotyczy tu wykonywania serii ćwiczeń poświęconych określonemu zagadnieniu, poczynając od wyboru właściwej formy, dokonywanych transformacji leksemów i zdań po coraz bardziej 
złożone oraz swobodne wypowiedzi uczących się ${ }^{6}$. Powtarzalność czynności obejmuje również większe przedziały czasowe, gdyż po wprowadzeniu określonych konstrukcji uczący się są obligowani do ich regularnego używania (gdy nauczyciel nie będzie o to zabiegać, to wysiłek, jaki towarzyszył wprowadzaniu określonych reguł, szybko zostanie zaprzepaszczony).

Anna Seretny i Ewa Lipińska stwierdzają, że „Uczenie się gramatyki kojarzy się zwykle z monotonią, nudą, nieustannym, często wręcz bezrefleksyjnym, automatycznym powtarzaniem. Nie ulega wątpliwości, że istnieje wiele rozmaitych technik i materiałów, dzięki którym można uatrakcyjnić zajęcia gramatyczne"7. Już w samych podręcznikach odnajdujemy ciekawe pomysły na to, jak wprowadzać, utrwalać i wykorzystywać poszczególne struktury gramatyczne, dbając przy tym o różnorodność technik nauczania oraz wykonywanych ćwiczeń ${ }^{8}$. Wystarczy odrobina inwencji, by urozmaicać sposoby utrwalania nauczanych reguł, łączyć naukę z zabawą i angażować uwagę uczących się. Jak podsumowuje Hanna Komorowska: „w wyniku zastosowania gier, zabaw językowych i zgadywanek uzyskujemy wypowiedzi często identyczne z tymi, jakie przyniosłyby monotonne ćwiczenia gramatyczne" . W niniejszym artykule skupimy się na propozycji krótkich zadań, których celem jest upowszechnianie pożądanych form (oraz zwalczanie związanych z nimi interferencji).

Przy utrwalaniu poprawnych form mianownika, którego niewłaściwa forma skutkuje doborem niewłaściwego paradygmatu fleksyjnego (*to jest dentyst, *idę do dentysta, *jestem dentystem), wskazane są rozsypanki literowe i krzyżówki (uczeń, mając do dyspozycji określoną liczbę liter bądź kratek, dostrzega konieczność użycia jeszcze jednej litery, co sprzyja zapamiętywaniu właściwej formy). Dobrym ćwiczeniem są tu zwłaszcza wykreślanki. Nieostrożny uczeń będzie zaznaczał ciągi typu poet, artyst, dentyst, nie zdając sobie sprawy z tego, że nie jest to cały wyraz i należy uwzględnić jeszcze jedną literę.

O ile w wypadku rozsypanki wyrazowej czy krzyżówki uczący się dysponuje wiedzą na temat liczby znaków, z których składa się odgadywane słowo, o tyle w poniższym ćwiczeniu musi już zachować większą czujność przy zaznaczaniu internacjonalnych nazw tych zawodów, które w języku polskim kończą się na $-a$ i w liczbie pojedynczej odmieniają się według wzoru deklinacji żeńskiej.

\footnotetext{
${ }^{6}$ A. Seretny, E. LipińsKa, ABC metodyki nauczania języka polskiego jako obcego, Kraków: Universitas 2005, s. 121

${ }^{7}$ Tamże, s. 116.

${ }^{8}$ Tamże, s. 116-133.

${ }^{9}$ H. Komorowska, Metodyka nauczania języków obcych, Warszawa: Fraszka Edukacyjna 2005, s. 71.
} 


\section{Jakie są tutaj zawody?}

\begin{tabular}{|c|c|c|c|c|c|c|c|c|c|}
\hline P & I & L & O & T & D & O & I & M & F \\
\hline I & G & L & R & K & E & L & N & E & R \\
\hline A & P & E & A & A & N & E & Z & C & Y \\
\hline N & O & K & T & K & T & K & Y & H & Z \\
\hline I & E & A & R & T & Y & S & T & A & J \\
\hline S & T & R & Z & O & S & A & O & N & E \\
\hline T & A & Z & R & T & T & K & R & I & R \\
\hline A & K & T & O & R & A & L & I & K & A \\
\hline
\end{tabular}

Wskazaną rzeczą przy utrwalaniu wymaganych form stają się także transformacje językowe oraz uzupełnianie luk w tekstach (rozwijanych, modyfikowanych) dowcipów, które pozwalają urozmaicić ćwiczenia gramatyczne i nadać im atrakcyjniejszy kształt. Przy utrwalaniu form leksyjnych przydatne stają się dowcipy oparte na dialogach o paralelnie zbudowanych zdaniach, których zasób można rozbudowywać. Na przykład ćwiczeniu narzędnika dobrze służy niniejszy tekst:

Pani pyta dzieci, kim chcą być. - Ja chce być (aktorka) - mówi Ania. - A dlaczego? - pyta nauczycielka. - Bo interesuje sie (filmy).

- A ja chcę być (pianista), bo interesuję się (muzyka klasyczna) - mówi Staś. (...) - A ja chcę być (święty Mikołaj) - mówi Jaś. - A to dlaczego? - pyta nauczycielka. - Bo chce pracować tylko jeden dzień wroku.

Zapamiętywaniu różnicy między czasownikami wiedzieć a znać sprzyja zaś poniższy dowcip:

- Tato, czy (wiesz / znasz), ile kilometrów ma Wista? - Nie (wiem / znam). - A czy (wiesz / znasz), kto to jest Mickiewicz? - Nie (wiem / znam). - A (wiesz / znasz), gdzie jest Gdańsk? - Nie (wiem / znam). - Synku, skończ z tymi pytaniami. Tata chce odpoczywać - prosi mama. - Nic nie szkodzi - mówi tata. - Nie (wiesz / znasz) podstawowej zasady? Jeśli nie będzie pytać, to niczego się nie dowie. 
Teksty humorystyczne - poprzez swoją różnorodność oraz łatwość ich adaptowania do celów glottodydaktycznych - pozwalają łączyć naukę gramatyki z zabawą, uatrakcyjniać ćwiczenia i inspirować do budowania kolejnych dialogów (np. uczniowie dostają kartki z nazwami różnych postaci, przedmiotów, miejsc geograficznych i, odwołując się do nich, mają zadawać pytania, które zaczynają się od formuły: czy wiesz..., czy znasz...).

Utrwalaniu poprawnych form służy też odgadywanie bądź uzupełnianie podawanych haseł, przysłów, piosenek, wierszyków. Przy sprawdzaniu znajomości form fleksyjnych warto wykorzystać grę w Koło fortuny, wybierając takie hasła, które - na skutek interferencji - mogą być błędnie odgadywane. Stosunkowo proste wyrażenia: np. $\mathrm{N}_{-} \mathrm{CZ}_{-} \mathrm{C}_{-} \mathrm{L}_{-} \mathrm{M}_{-} \mathrm{Z}_{-} \mathrm{K}_{-}, \mathrm{W}_{-} \mathrm{R} \mathrm{S} \mathrm{Z}_{-}$ $\mathrm{D} \mathrm{L}_{-} \mathrm{D} \mathrm{Z}_{-} \mathrm{E} \mathrm{C}$ _okazują się trudne do odgadnięcia, a podawane wersje (*nauczycieli muzyki, *wierszy dla dzieci) nie są zaliczane, skłaniając odgadujących do większej rozwagi przy rozwiązywaniu zagadki. W wypadku uzupełnianych wierszyków i piosenek podawaniu poprawnych odpowiedzi sprzyja obecność rymów, które ukierunkowują sposób uzupełnienia luk wyrazowych. Popularny wierszyk o panu Hilarym staje się pomocny przy ćwiczeniu form miejscownika (w spodniach, surducie, bucie, kanapie, piecu, kominie, dziurze, pianinie, nosie). Wiersz o leniu, który nic nie robi cały dzień, pozwala przećwiczyć formy czasu przeszłego, stanowiąc impuls do stworzenia karty z dziennika leniwego oraz pracowitego ucznia bądź leniwej i pracowitej uczennicy.

Utrwalaniu odpowiednich form służy też dopasowywanie autentycznych bądź wymyślonych tytułów (np. Świetni sportowcy, Odważni rycerze, Dawni królowie, Sławni aktorzy, Znani piosenkarze, Wielcy Polacy, Straszni piraci) do ilustracji, a następnie wybór jednej z tak zatytułowanych „książek” oraz krótkie umotywowanie podjętej decyzji (bądź zareklamowanie wybranego albumu) ${ }^{10}$. W ten sposób można powtarzać kłopotliwe formy, do których właśnie przynależy mianownik liczby mnogiej rzeczowników męskoosobowych ${ }^{11}$.

Przydatnymi rekwizytami, które pozwalają sprawdzić znajomość wymaganych reguł, stają się małe koszyki oraz karteczki z nazwami, które należy odpowiednio pogrupować. Zestawu koszyków można używać już od pierwszych

\footnotetext{
${ }^{10}$ Inspiracją tego ćwiczenia stały się książki z serii Strrraszna historia, których tytuły: $\mathrm{Ci}$ odjazdowi jaskiniowcy, Ci paskudni Aztekowie, Ci niewiarygodni Inkowie, Ci koszmarni Celtowie, Ci niesamowici Egipcjanie, Ci rewelacyjni Grecy są co prawda zbyt trudne jak na poziomy A2, B1, lecz dostarczają impulsu do tworzenia prostszych tytułów z użyciem rzeczowników męskoosobowych, które należy połączyć z ilustracją - okładką hipotetycznego albumu.

${ }^{11}$ Dominika Izdebska-Długosz stwierdza, że problemy z rodzajem męskoosobowym znajdują się w czołówce wszystkich trudności z gramatyką polską, jakie mają uczący się polskiego użytkownicy języków wschodniosłowiańskich (,Czyje są te syny?”, s. 44).
} 
lekcji, gdy omówieniu podlega podział rzeczowników na rodzaj męski, żeński oraz nijaki. Uczący się otrzymują kartki z rzeczownikami w liczbie pojedynczej i mają je wrzucić do odpowiedniego koszyka oznaczonego symbolem danego rodzaju (np. jeden koszyk jest przewiązany muchą, drugi kokardą, a na trzecim zostaje umieszczony smoczek dziecięcy). Koszyki mogą być wykorzystywane wielokrotnie przy utrwalaniu licznych zagadnień gramatycznych. Na przykład przy ćwiczeniu form dopełniacza rodzaju męskiego uczniowie otrzymują kartki z różnymi nazwami i muszą zdecydować czy umieścić je w koszyku z literką -A czy -U, przy ćwiczeniu form celownika pojawiają się koszyki -OWI oraz -U, przy ćwiczeniu form liczebnika - koszyki: DWAJ, DWA, DWIE itp. Po wykonaniu zadania nauczyciel sprawdza zawartość koszyków, słucha opinii uczących się, pomaga rozsądzać spory. Zestaw form pochodzących z wybranych koszyków staje się następnie podstawą tworzonych dialogów, scenek, opowiadań (ważny jest więc taki dobór nazw, aby ich wydzielone zbiory inspirowały do tworzenia ciekawych historii).

Przy powtarzaniu wybranych form fleksyjnych nieoceniona jest gra memory, która pozwala sprawdzać nie tylko pamięć oraz znajomość słownictwa, ale i stopień opanowania wybranych reguł gramatycznych. Na przykład przy odsłonięciu dwóch tych samych osób czy przedmiotów można utrwalać formę mianownika liczby mnogiej (to sq uczniowie, to sq uczennice), dopełniacza liczby mnogiej (to jest para uczniów, para uczennic), biernika liczby mnogiej (znalazłem / znalazłam uczniów, uczennice), konstrukcji liczebnikowych (to sq dwaj uczniowie, dwie uczennice, dwa rowery).

Utrwalaniu zasad użycia długich oraz krótkich form zaimków dobrze zaś służą rozsypanki zdaniowe. $Z$ pojedynczych słów zapisanych na planszach (np. ZNAM, LUBIĘ, MÓWIĘ, DO, GO, JEGO, NIEGO) należy układać krótkie zdania, dbając o ich poprawność gramatyczną i nie myląc zaimków. Do utrwalania reguły zamiany formy biernika na dopełniacz w zdaniach przeczących także warto użyć kartek z pojedynczymi słowami, z których uczący się powinni ułożyć poprawną konstrukcję. Na przykład, mając do dyspozycji plansze ze słowami MAM, CZARNA, CZARNĄ, CZARNEJ, KURTKA, KURTKI, KURTKĘ, uczący się układa zdanie: MAM CZARNĄ KURTKE, a gdy zdania z biernikiem są już poprawnie ułożone, nauczyciel dodaje do nich czerwoną kartkę ze słowem NIE, wymagając przeformułowania ułożonego zdania, odrzucenia plansz z konstrukcją biernikową i sięgnięcia po formy dopełniacza, co sprzyja zapamiętywaniu jednej z podstawowych reguł gramatycznych.

W procesie wielokrotnie powtarzanych zasad warto też wymyślać i powtarzać krótkie rymowanki, których funkcją jest upowszechnianie właściwych form. Proste zdania typu: Sto lat uczę, że mówimy klucze, A ja ciagle marzę, 
że powiecie lekarze (kucharze, piłkarze, garaże itp.) pozwalają przypomnieć właściwą końcówkę mianownika liczby mnogiej rzeczowników zakończonych na spółgłoskę miękką i stwardniałą (w wyniku interferencji pojawiają formy *kluczy, *lekarzy uznawane za mianownik liczby mnogiej). Wraz z powtarzalnością danych rymowanek już sama aluzja do nich (np. poprzez pytania: Czego sto lat uczę? O czym ciagle marzę?) sprawia, że uczący się przypominają sobie regułę i używają odpowiedniej formy.

Ustną korektę warto jeszcze wspomagać gestem - np. gdy uczący się używa sformułowań: to jest dentyst, on jest dentyst, nauczyciel składa dłonie w kształt litery A i wypowiada właściwą formę słownikową (dentysta), kładąc nacisk na ostatniej głosce. Słysząc zwrot: *pracować inżynierem i upowszechniając poprawną strukturę ( pracować jako ktoś), nauczyciel pokazuje trzy palce, „przypisując” każdemu z nich jeden komponent werbalny i sygnalizując konieczność użycia trzech słów. Gdy uczący się stosuje biernik tuż po zaprzeczonym czasowniku, nauczyciel może użyć metaforycznej frazy: biernik do kosza, wykonując gest zgniatanej i wyrzucanej kartki. Słysząc konstrukcje: do uniwersytetu, w uniwersytecie, warto zademonstrować gest otwartych dłoni, które - towarzysząc dokonywanej korekcie - symbolizują otwartą przestrzeń oraz związaną z tym konieczność użycia przyimka na. Słysząc długie formy zaimków po czasownikach (lubię jego), nauczyciel może zbliżać otwarte dłonie do siebie, nakazując posłużenie się krótszą formą.

W toku interakcji z uczącymi się takie gesty powstają spontanicznie, a ze względu na istotność swojej funkcji stają się świadomie wykorzystywanymi narzędziami. Wraz z powtarzalnością danych gestów oraz towarzyszących im uwag uczący się zaczynają pojmować znaczenie stosowanych przez nauczyciela znaków, których katalog można wzbogacać i modyfikować zależnie od doświadczanych potrzeb. Po pewnym okresie już sam gest wystarczy, by uczący się zrozumiał, jaki błąd popełnił i jakiej korekty powinien dokonać (zmniejsza się także czas reakcji na pokazywany przez nauczyciela znak).

\section{PODSUMOWANIE}

Pokrewieństwo języka wyjściowego oraz docelowego ma tę zaletę, że znacznie przyspiesza proces nauki oraz pozwala przewidywać, z jakimi konstrukcjami uczący się będą mieć najwięcej problemów i jakie błędy będą wielokrotnie popełniać. Na podstawie literatury glottodydaktycznej oraz własnych doświadczeń można więc przygotowywać ćwiczenia obliczone właśnie na zwalczanie interferencji oraz opracowywać sposoby jak najbardziej efektywnego nauczania 
reguł gramatycznych ${ }^{12}$. Co istotne, ukraińskojęzyczni uczniowie wykazują duże zainteresowanie polską gramatyką, oczekując od nauczyciela przejrzystego wyjaśniania jej reguł i czerpiąc wyraźną satysfakcję z ich opanowywania. Ważne jest więc to, by powoli zwiększać stopień trudności i dbać o to, by uczący się nie odczuwali nadmiernego ciężaru ćwiczeń. Do zwiększonego nacisku na rozwijanie kompetencji gramatycznej przyczyniają się także egzaminy certyfikatowe z języka polskiego, w których poprawność gramatyczna jest przedmiotem odrębnego modułu i podlega uwzględnieniu także przy ocenie wypowiedzi pisemnej oraz ustnej.

O ile błędy popełniane przez początkujących Ukraińców odznaczają się dużą powtarzalnością i schematycznością, o tyle sposoby zwalczania interferencji przybierają różnorodny charakter. Istotne są techniki automatyzujące, ćwiczenia na wybór oraz transformacje, lecz wskazane są również takie działania, które pozwalają przypominać reguły polskiej gramatyki i skłaniać uczących się do dostrzegania popełnianych błędów oraz samodzielnego dokonywania ich korekty.

\section{LITERATURA}

Baraniwska O., Polsko-ukraińskie interferencje gramatyczne i leksykalne w nauczaniu języka polskiego jako obcego, w: Literatura, kultura i język polski w kontekstach i kontaktach światowych, red. M. Czermińska, K. Meller, P. Fliciński, Poznań: Wydawnictwo Naukowe UAM 2007, s. 747-753.

Czernysz T., Polsko-ukraińskie pułapki językowe: korzyści i trudności nauczania języka polskiego w kontekście bliskości lingwogenetycznej i typologicznej, w: Nauczanie języka polskiego jako obcego i polskiej kultury w nowej rzeczywistości europejskiej, red. P. Garncarek, Warszawa: Uniwersytet Warszawski 2005, s. 477-481.

Dąbrowska A., Dobesz U., Pasieka M., Co warto wiedzieć. Poradnik metodyczny dla nauczycieli języka polskiego jako obcego na Wschodzie, Warszawa: Ośrodek Rozwoju Edukacji 2010.

Dunin-Dudkowska A., Maliszewski B., Jak lepiej (nie) pisać? O błędach popetnianych przez Ukrainców zdających egzamin certyfikatowy z języka polskiego jako obcego, w: Polonistyka w XXI wieku: między lokalnym a globalnym, red. A. Krawczuk, I. Bundza, Kijów: Firma INKOS 2018, s. 354-363.

Górecki M., Stawska M., Błędy językowe charakterystyczne dla młodzieży polskiej ze Wschodu, w: Metodyka kształcenia językowego Polaków ze Wschodu, red. J. Mazur, Lublin: Wydawnictwo UMCS 1993, s. 49-55.

${ }^{12}$ Zob. A. Krawczuk, J. KowalewsKi, Jestem stąd. Międzykulturowy podręcznik komunikacyjny do języka polskiego, Lwów: Narodowy Uniwersytet Lwowski im. I. Franki 2013, D. IzDEBSKA-DŁUGosz, Zbiór ćwiczeń z gramatyki języka polskiego dla studentów ukraińskojęzycznych: Al - B1, Rzeszów: Stowarzyszenie Społeczno-Ekonomiczne Absolwent 2017. 
IzDebsKa-DŁugosz D., „Czyje sq te syny?”, czyli o błędach w rodzaju męskoosobowym popetnianych przez studentów ukraińskojęzycznych, w: Horyzonty nauczania języka polskiego jako obcego, red. A. Roter-Bourkane, A. Kwiatkowska, Poznań: TetraStudio 2016, s. 43-57.

Izdebska-DŁugosz D., Po polsku bez błędu: Zbiór ćwiczeń z gramatyki języka polskiego dla studentów ukraińskojęzycznych: A1 - B1, Rzeszów: Stowarzyszenie Społeczno-Ekonomiczne Absolwent 2017.

Komorowska H., Metodyka nauczania języków obcych, Warszawa: Fraszka Edukacyjna 2005.

KowalewsKi J., Czy można się uczyć na błędach? Wnioski dydaktyczne wynikajace z analizy błędów popetnianych przez uczacych się języka polskiego na Ukrainie, w: Język polski i polonistyka w Europie Wschodniej: przeszłość i współczesność, red. I. Bundza, J. Kowalewski, A. Krawczuk, Kijów: Firma INKOS 2015, s. 361-376.

KRAwCZuK A., Błędy gramatyczne studentów polonistyki lwowskiej spowodowane polsko-ukraińska interferencja, ,Postscriptum” 2(2006), s. 137-153.

KrawczuK A., Kowalewski J., Jestem stąd. Międzykulturowy podręcznik komunikacyjny do języka polskiego, Lwów: Narodowy Uniwersytet Lwowski im. I. Franki 2013.

Maliszewski B., Per errata ad astra - zwalczanie interferencji gramatycznych $w$ procesie nauczania języka polskiego studentów ze Wschodu, w: Błąd w literaturze, kulturze i językach narodów słowiańskich, red. M. Dziwisz et al. Lublin: Wydawnictwo UMCS 2014, s. 221-230.

PrzeChodzKa G., Z problematyki interferencji językowej w nauczaniu języka polskiego Polaków ze Wschodu, w: Metodyka kształcenia językowego Polaków ze Wschodu, red. J. Mazur, Lublin: Wydawnictwo UMCS 1993, s. 39-48.

Seretny A., LipińsKa E., ABC metodyki nauczania języka polskiego jako obcego, Kraków: Universitas 2005.

\section{KU ABSENCJI INTERFERENCJI - SPOSOBY UTRWALANIA POPRAWNYCH FORM GRAMATYCZNYCH W NAUCZANIU JĘZYKA POLSKIEGO MŁODZIEŻY Z UKRAINY}

\section{Streszczenie}

Autor podejmuje temat interferencji językowych, koncentrując się jednak nie tyle na kategoryzacji poszczególnych błędów oraz ich charakterze, co na ogólniejszym problemie - jak eliminować interferencje w ustnych i pisemnych wypowiedziach młodzieży ze Wschodu rozpoczynającej naukę języka polskiego jako obcego. Artykuł składa się z dwóch części - w pierwszej są pokrótce przedstawione typowe błędy wschodnich Słowian uczących się języka polskiego jako obcego. W drugiej zaś - przedstawione są przykłady ćwiczeń, które - stwarzając pole do interferencji językowych - pozwalają utrwalać te reguły języka polskiego, z którymi wschodni Słowianie mają najwięcej problemów.

Słowa kluczowe: glottodydaktyka; gramatyka; interferencja językowa; błąd. 


\section{TOWARDS THE ABSENCE OF INTERFERENCE - \\ THE WAYS OF INTERNALIZING THE CORRECT GRAMMATICAL FORMS \\ IN THE TEACHING POLISH LANGUAGE OF YOUNG PEOPLE FROM THE UKRAINE}

\section{Summary}

In this paper, the author discusses language interference, focusing not only on the categorisation of particular errors and their character but also on the general issue of how to eliminate interferences in oral as well as written utterances of the young students from Eastern Europe who are just starting to learn Polish as a foreign language. The paper is divided into two parts. The first part presents typical errors made by the Eastern European students learning Polish as a foreign language. In the second part, the author presents the example tasks which - by creating an area for language interferences - allow to consolidate those rules of the Polish language, with which the students from Eastern Europe have most problems

Key words: glottodidactics; grammar; language interference; error. 